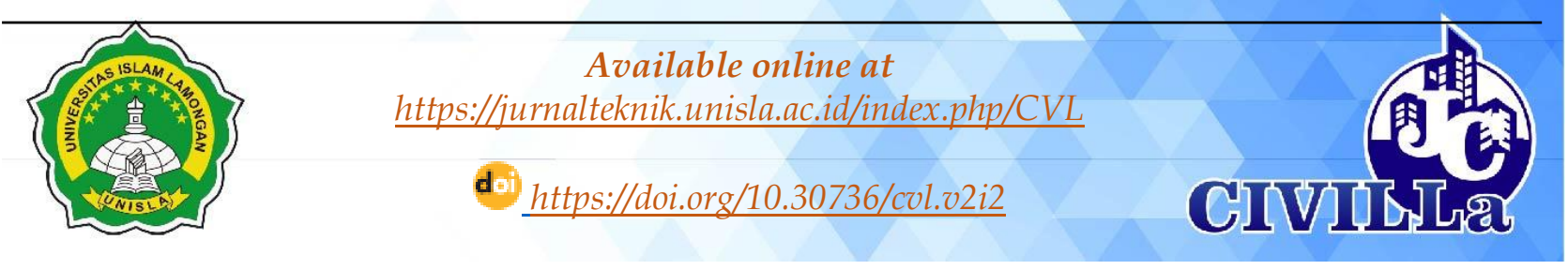

\title{
Study of Progress Expected Results Based on Percentage of Construction Work Plan Duration
}

\author{
Mardiaman $^{1}$, Edward Kusuma ${ }^{2}$ \\ ${ }^{1}$ Faculty of Engineering \\ ${ }^{2}$ Faculty of Engineering. \\ Email: 1 mardi240967@gmail.com.
}

\section{A R T I C L E IN F O}

\section{Article History :}

Article entry : 2021-07-18

Article revised : 2021-09-23

Article received : 2021-10-16

Keywords :

Progress, Expected Value, Plan

Time Duration Waktu,

Construction Work

IEEE Style in citing this article : M. and E. Kusuma, "Study of Progress Expected Results Based on Percentage of Construction Work Plan Duration," CIVILA, vol. 6, no. 2, pp. 167-180, 2021.

\section{A B S T R A C T}

Controlling how construction work is completed is critical to success. Generally, the result value method is used as the tool. Although this method has been applied to a variety of different types of construction work, the tool has been limited to a single project. This study examines the total value of completed construction work. Because the duration of construction work varies, the researchers refer to the percentage of the plan's duration. The percentages are set at 25\%, 30\%, and 50\%. There have been 17 completed building construction projects between 2017 and 2018. Additionally, a comparison sample of construction work is used. The results of the data processing are pessimistic, most likely, optimistic, and hopeful. Additionally, the expected value is compared to a reference value. The expected values for the percentages of $25 \%, 30 \%$, and $50 \%$ are $(-2.425),(1.071)$, and $50 \%$, respectively (2.275). Indeed, the expected value obtained is not the same as the comparison value. The contractor can prepare the necessary resources by knowing the value of the expected yield at a certain percentage of the duration. 


\section{Introduction}

The degree of uncertainty associated with the execution of construction work is extremely high. The contractor completes the construction work in accordance with the schedule. It is established that there is a difference in the value of schedule and cost deviations [1]. The variation in result values is caused by the reduction of both actual and planned progress. Positive values indicate superior performance, and negative values indicate inferior performance. A positive cost deviation indicates profit, while a negative cost deviation indicates cost overrun. The factors that contribute to delays have received considerable attention [2];[3]. Meanwhile, schedule deviations that are negative result in delays. Factors that contribute to delay [4];[5].

In construction practice, the value of the results is evaluated weekly and documented in a weekly report. Cost and time are two variables that affect progress. Cost and time can be managed in unison[6]. Knowing the yield value at a particular point in time will assist in completing the remainder of the construction work [6].

Numerous construction projects have been evaluated using the yield value method [7],[8]. [12]; [9]; [10]; [11]. However, yield value research is typically limited to a single construction job. The purpose of this study is to thoroughly examine the value of the results from 17 building construction projects with varying plan durations. Due to the fact that the duration of each construction work varies, the same reference must be made based on the percentage of the planned time duration of each construction work.

When construction work is just getting started, the yield value's deviation is still zero. However, once construction work has been completed for a specified period of time, time and cost variations are common. Additionally, at the conclusion of a large project, the yield value's deviation becomes zero. This occurs because the work must be completed completely at the conclusion of the contract and handed over. The purpose of this study is to determine the value of actual and planned deviations based on the percentage of the work's duration that is completed at a rate of $25 \% .30 \%$ and $50 \%$ of the plan's duration, respectively. The magnitude of the deviation between the result values and the target time duration will be determined for each percentage of the target time duration. Because construction work involves a great deal of uncertainty, the expected value is determined using the three values above: pessimistic, most likely, and optimistic.

This research assists contractors in determining the value of progress results at $25 \%, 30 \%$, and $50 \%$ of the planned duration of the construction work, so that the contractor can prepare the necessary resources and take corrective action. .

\section{Review of the theory}

\subsection{Control of Construction Work}


Numerous variables have an effect on the performance of construction work[13].

Controlling the construction process entails monitoring all resources and site arrangements. Control must be exercised over activities that follow critical paths that are interdependent. Begin monitoring at the initial critical activity to ensure that corrective action is taken as soon as possible [12]. Knowing the value of the results and communicating them in weekly meetings will assist in making quick decisions. By comparing actual and planned performance, the result value is determined. Controlling factors include the following: 1) Time-related factors, 2) Performance-related factors, and 3) Cost-related factors.

Control is accomplished by examining the $\mathrm{S}$ curve of work progress as reported in weekly meetings. The causes of work progress non-conformance are identified. Acceleration efforts are made by optimizing resource allocation and supervision.

\subsection{Cost of Construction}

Costs associated with construction include wages, materials, equipment, and interest on capital. The cost of construction work is determined by a variety of variables. Price is affected by the location factor [14]. The percentage of resource costs varies according to project[15]. Calculation of construction costs through the use of various models, parametric models[16] The method of integrated time and cost management will generate the following cost versus time matrix: Cost overruns and schedule delays are indicators of poor project management.

\subsection{Protracted duration of the project}

The factors that contribute to the delay have been identified[17]. Numerous factors contribute to delays in the execution of construction work, including reporting [6] and ranking the factors that contribute to delays[18]. Cost overruns occur as a result of project delays[19];[20];[21];[2]. Delay has a detrimental effect [22]. The delay's cause has been determined[23];[24]

\subsection{The Concept of Earned Value}

The value parameter (planned value) and the value obtained (actual value) can be used to determine the progress of the work[25]. Yield value analysis and control is a powerful technique for analyzing and controlling project performance, as well as acting as a warning sign. The graph $\mathrm{S}$ curve and schedule table both illustrate this warning sign [26]. Monitoring time and cost with the help of yield values is advantageous [27]. Yield value management has been successfully implemented in a variety of sectors of the construction industry, including construction projects[7], 
residential buildings[28], and commercial buildings[29]. Efficient and well-known for project management, as a method for managing time differently[30]. Value for results is a concept that refers to a system that can integrate time and cost data. However, this method has a weakness in that its sensitivity is high enough that it can be used in conjunction with another method. [31] The results were valued according to their control over time, cost, and project scope [32] ]. Six parameters are used in the result value, including 1) the estimate at completion. 2) the completed budget, 3) the schedule performance index, 4) the cost performance index, 5) the schedule variance, and 6) the cost variance.

Progress value $=$ actual-planned progress value

\subsection{Expected Rate of Progress}

It is impossible to predict the cost, duration, and progress of construction work. The contractor charges the project owner for the progress of the work. This uncertainty is quantifiable in terms of probability, allowing for pessimistic, most likely, and optimistic values. Progress is measured by the cumulative weight of work accomplishments at a given point in time.

Activity weight $=X \_i /\left(\sum \_(i=1)^{\wedge} n_{\text {w }}\right.$ w: $\left.X \_i\right) \times 100 \%(2)$

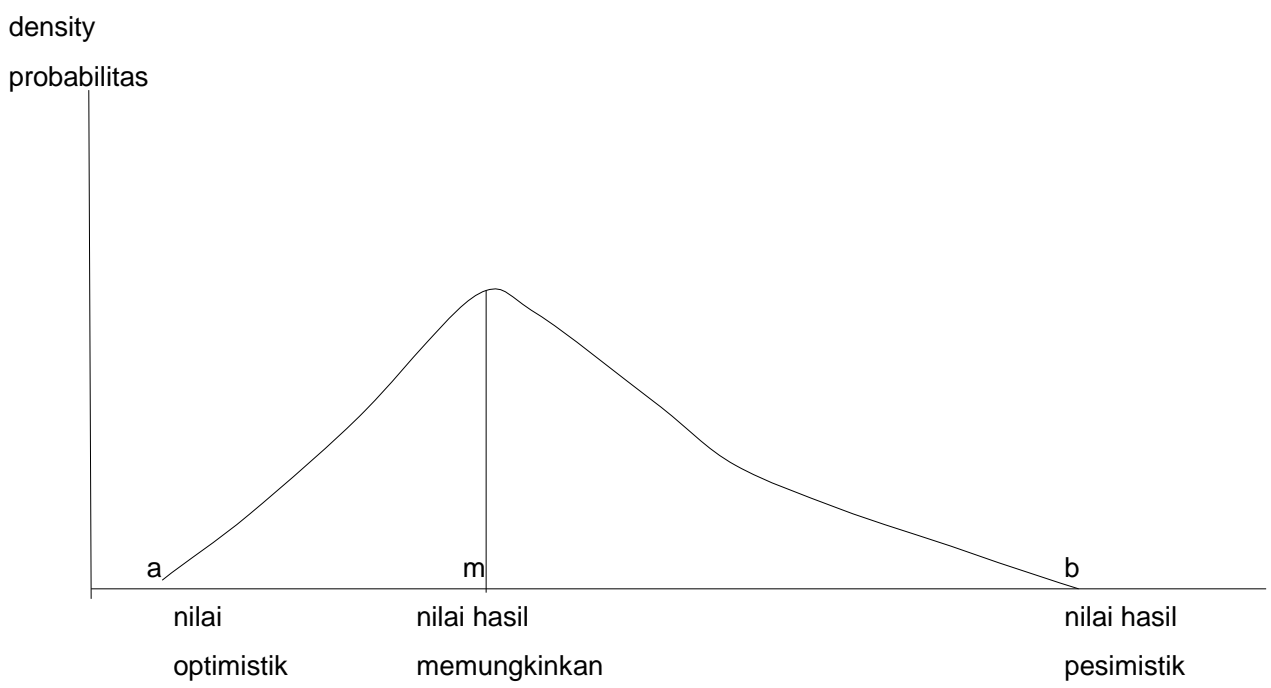

Figure 1. The expected value approach assumes that the expected value for the yield value depends on the three-digit estimate.

$t_{e}=(a+4 m+b) / 6$

$\mathrm{a}=$ minimum yield value

$\mathrm{m}-$ most likely result value

$\mathrm{b}=$ maximum yield value

te $=$ expected result value 


\section{Methodology of Research}

Seventeen data points pertaining to the earned value of completed construction work from March to June 2021. Construction work plans typically last between 24 and 55 weeks. To determine the value of the deviation, a sample of construction work with a planned duration of 13 weeks is used as a comparison.

Due to the fact that the duration of the plan for each construction work varies, one approach is to make the same reference based on the percentage of the duration of the construction plan, which is $25 \%, 30 \%$, or $50 \%$. The deviation value was $25 \%$ x 24 weeks $=$ six weeks for the duration of the construction plan, which was 24 weeks. Thus, week six serves as a review. Similarly, all construction projects are treated as such.

Additionally, the following steps calculate the value of the anticipated job results.:

- Calculate the weekly deviation in progress for all construction projects.

- Calculate the mean, median, and maximum deviations for all construction projects.

- Calculating the construction work's expected progress

- The expected deviation value is progressing according to the formula:

$$
t e=(a+4 m+b)(1 / 6)
$$

Where:

$\mathrm{a}=$ optimistic progress

$\mathrm{b}=$ pessimistic progress

$\mathrm{m}=$ most likely progress

- Calculate the deviation in progress during the activity for $25 \%$ of the plan's duration.

- Calculate the deviation in progress when the activity lasts $30 \%$ of the time planned.

- Calculate the progress deviation when the activity is carried out for $50 \%$ of the planned duration.

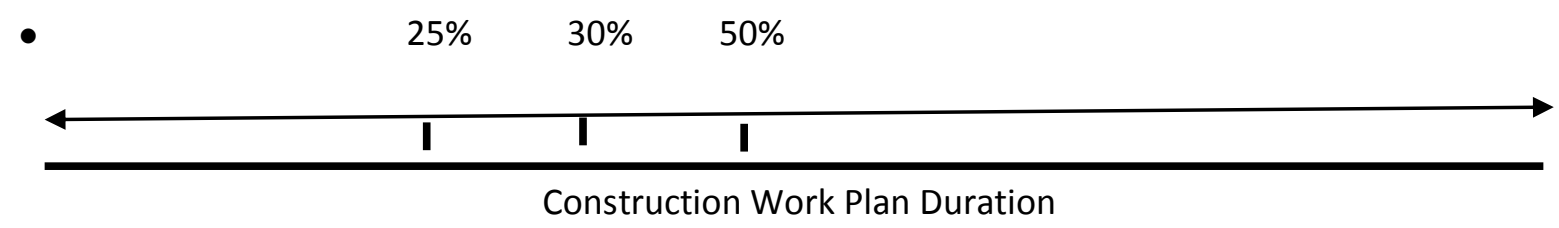

Source: Author's documentation 2021

Figure 2 . Percentage of construction work plan duration

Furthermore, the expected value is tested on other construction work, which is used as a comparison. The comparison project is a school building with a planned duration of 13 weeks. 


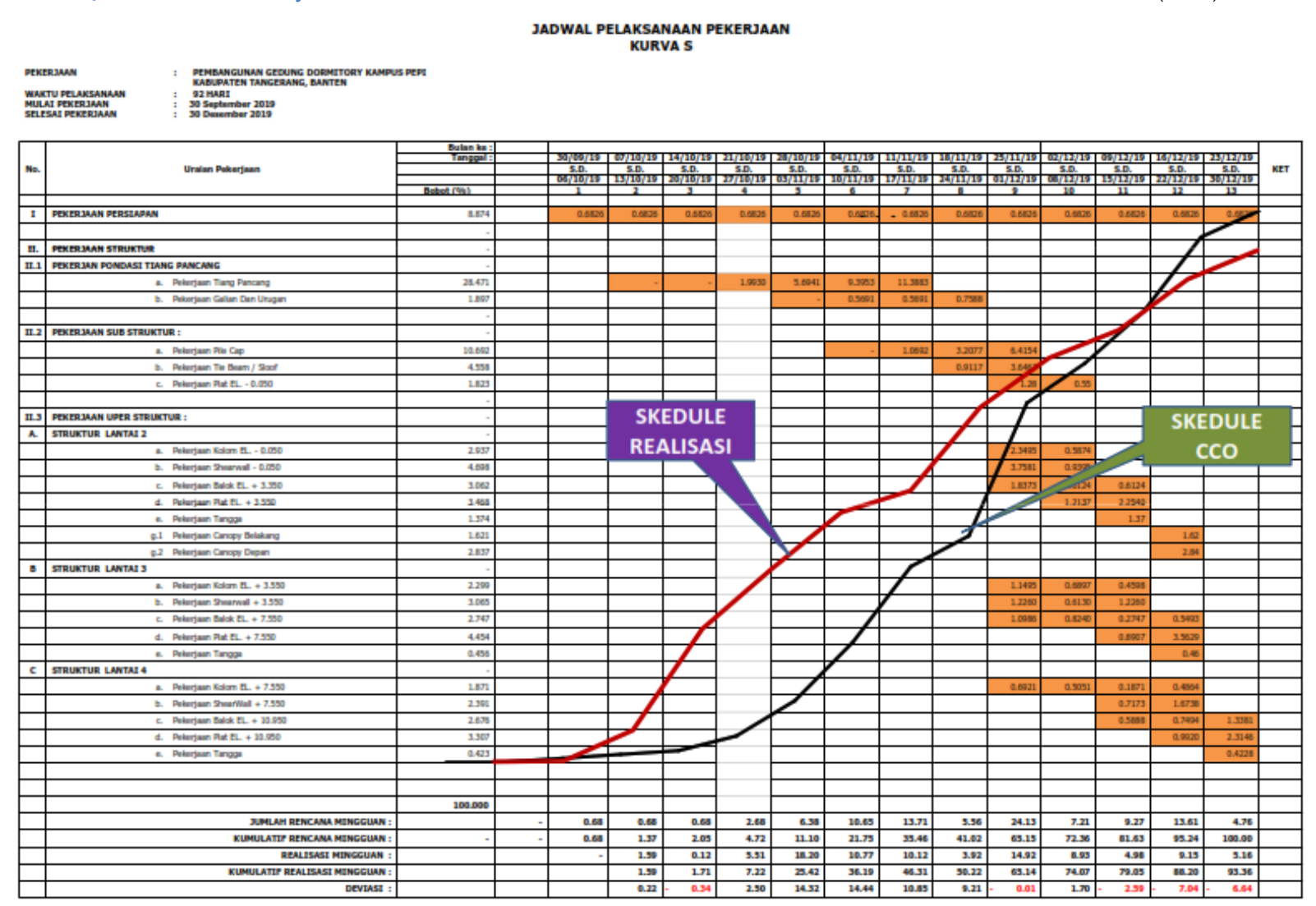

Figure 3 Comparative Construction Works

\section{Conclusions and Discussion}

\subsection{Result}

The value of the progress deviation for each of the seventeen construction projects can be displayed (table 1). These values are calculated as the difference between the field's actual and planned values. The results have a different monetary value for each reporting period. The construction work schedule typically lasts between 21 and 55 weeks. Additionally, a 13-week comparison project was conducted for the campus dormitory building.

As shown in Table 2, the value of progress obtained when the duration of the planned period is $25 \%$ of the actual duration is pessimistic (-12.23), most likely (-0.915), and optimistic (1.173), the expected value (-2.425). Additionally, the predicted value is compared to a comparison using the same reference, specifically when the plan duration is $25 \%$. The benchmark time then becomes the 3.25th week. (rounded up to the nearest three) and the resulting value is 0.220 .

At $30 \%$ of the duration, the deviation of the progress results in pessimistic values (-11.77), most likely (-0.189), and optimistic (6.104), expected values (1.071). When compared to the deviation value in the comparison project, which occurred in $30 \%$ of the 13 weeks that fell on the 3.9 week, rounded up to four, the variation was 0.34 .

At $30 \%$ of the duration, the deviation of the progress results in pessimistic (-4.102), most likely (-0.095), and optimistic (6.104) expected values (2.275). In comparison to the deviation value 
in the comparison project, which was 10.85 , which occurred at $50 \%$ of the 13 weeks that fell on the 3.9 week, rounded up to 7 .

\subsection{Discussion}

The data analysis results indicate that the expected value tends to increase as the duration of the starting time is increased by $25 \%(-2.425), 30 \%$ by (1.071), and $50 \%$ by (2.275). Initially, the deviation value was negative due to field constraints, such as a lack of parallel work, but there was still a match between the plans and implementation drawings. With increased time and equipment productivity, workers can perform more efficiently. Jobs on a critical path receive critical attention.

The finished construction work will never be identical in terms of time, cost, or quality. The data analysis confirmed the outcomes of the 17 construction projects listed above. Additionally, previous research has established this[1];[33];[10]; [34];[35]. Numerous factors contribute to the variance in the values of the results [36]. From the perspective of contractors and consultants, a contributing factor is the difficulty of making payments. Payment difficulties disrupt the procurement of resources, including material, labor, and equipment. The cost of acquiring construction resources varies by construction type[15] and location[14]. Consistency is required when allocating costs according to the prepared schedule. The contractor's financial performance is the primary factor in determining the tender winner's appointment[37]. 
Table 1. Progress Values for 17 Construction Projects

\begin{tabular}{|c|c|c|c|c|c|c|c|c|c|c|c|c|c|c|c|c|c|}
\hline \multirow[t]{2}{*}{ Minggu } & \multicolumn{17}{|c|}{ Progress Values for 17 Construction Projects } \\
\hline & 1 & 2 & 3 & 4 & 5 & 6 & 7 & 8 & 9 & 10 & 11 & 12 & 13 & 14 & 15 & 16 & 17 \\
\hline 1 & 0,3 & 0,3 & 0,1 & 0,03 & 0,152 & 0,03 & $-0,055$ & 0,03 & $-0,055$ & 0,03 & 0,08 & 0,02 & 0,02 & 0,2 & 0,05 & 0,03 & $-0,346$ \\
\hline 2 & 0,375 & 0,375 & 0 & 0,06 & $-0,466$ & $-0,14$ & $-0,784$ & $-0,14$ & $-0,784$ & 0,06 & $-0,083$ & 0,04 & 0,04 & 0,4 & 0,1 & 0,06 & $-0,899$ \\
\hline 3 & 0,675 & 0,675 & $-0,2$ & 0,09 & $-0,538$ & $-0,11$ & $-2,419$ & $-0,11$ & $-2,419$ & 0,09 & $-0,246$ & 0,06 & $-0,94$ & 0,6 & 0,15 & 0,09 & $-2,945$ \\
\hline 4 & 0,975 & 0,975 & $-0,3$ & 0,12 & $-0,209$ & $-0,08$ & $-3,914$ & $-0,08$ & $-3,914$ & 0,12 & $-0,278$ & $-0,92$ & $-1,92$ & 0,8 & 0,2 & 0,12 & $-2,936$ \\
\hline 5 & 1,275 & 1,275 & $-0,3$ & 0,15 & $-0,29$ & $-0,05$ & $-4,8$ & $-0,05$ & $-4,8$ & 0,15 & 0,135 & $-0,9$ & $-1,9$ & 1 & 0,25 & 0,15 & $-2,9$ \\
\hline 6 & 1,173 & 1,173 & 0,2 & 0,18 & $-0,97$ & $-0,12$ & $-4,681$ & $-0,12$ & $-4,681$ & 0,08 & 0,545 & $-1,28$ & $-1,88$ & 1,2 & 0,3 & 0,18 & $-1,087$ \\
\hline 7 & 1,029 & 1,029 & 0,6 & 0,21 & $-1,051$ & $-0,09$ & 1,002 & $-0,09$ & 1,002 & $-0,89$ & $-2,111$ & $-0,76$ & $-0,86$ & 0,8 & 0,35 & 0,21 & $-0,973$ \\
\hline 8 & 0,515 & 0,515 & 0,7 & 0,24 & $-1,531$ & 0,54 & 6,104 & $-0,46$ & 6,104 & $-0,96$ & $-6,245$ & $-0,04$ & $-2,84$ & 0,4 & 0,4 & $-0,56$ & $-0,651$ \\
\hline 9 & $-0,12$ & $-0,12$ & 1,2 & 0,27 & $-2,189$ & 0,57 & 4,973 & $-0,73$ & 4,973 & $-0,93$ & $-9,54$ & $-0,02$ & 0,18 & 0 & 0,45 & $-0,53$ & 0,782 \\
\hline 10 & $-2,085$ & $-2,085$ & 1,7 & 0,3 & $-2,913$ & 0,6 & 4,254 & $-0,7$ & 4,254 & $-0,9$ & $-12,229$ & 0 & 0,2 & $-0,4$ & $-0,3$ & $-0,5$ & 1,390 \\
\hline 11 & $-2,572$ & $-2,572$ & 1,2 & 0,33 & $-2,45$ & 0,63 & 2,073 & $-0,67$ & 2,073 & $-0,87$ & $-11,344$ & 0,02 & 0,22 & $-0,8$ & $-0,25$ & $-0,47$ & 2,447 \\
\hline 12 & $-3,418$ & $-3,418$ & 0,7 & 0,36 & $-2,486$ & 0,66 & 2,073 & $-0,64$ & 2,073 & $-0,84$ & $-11,773$ & $-0,66$ & 0,24 & 0 & $-0,2$ & $-1,44$ & 0,795 \\
\hline 13 & $-0,517$ & $-0,517$ & 0,2 & 0,39 & $-2,088$ & 0,49 & 2,103 & $-0,81$ & 2,103 & $-1,01$ & $-14,428$ & $-0,64$ & 0,26 & $-0,3$ & $-0,15$ & $-0,41$ & 0,092 \\
\hline 14 & $-0,217$ & $-0,217$ & $-0,3$ & 0,42 & $-1,291$ & $-0,08$ & 2,133 & $-0,38$ & 2,133 & $-1,58$ & $-15,521$ & $-0,62$ & 0,28 & $-0,7$ & $-0,1$ & $-0,38$ & 0 \\
\hline 15 & 0,083 & 0,083 & $-0,8$ & 0,35 & $-1,195$ & $-0,05$ & 2,163 & $-0,35$ & 2,163 & $-1,55$ & $-12,008$ & $-1,6$ & 0,3 & $-0,2$ & $-0,05$ & 0,65 & 0,581 \\
\hline 16 & 0,383 & 0,383 & $-1,3$ & 0,38 & $-0,1$ & $-0,02$ & 2,193 & $-0,32$ & 2,193 & $-1,52$ & $-11,504$ & $-1,58$ & 0,32 & 0,8 & 0 & 0,68 & 0,303 \\
\hline 17 & 0,458 & 0,458 & $-1,8$ & 0,41 & 1,247 & 0,01 & 2,223 & 0,31 & 2,223 & $-1,490$ & $-9,01$ & $-0,66$ & $-5,66$ & 0,3 & 0,05 & 0,71 & 0,917 \\
\hline 18 & 0,581 & 0,581 & $-2,3$ & 0,44 & 2,097 & 0,04 & 2,253 & 0,34 & 2,253 & $-1,460$ & $-5,66$ & $-0,64$ & $-5,64$ & 0 & 0,1 & $-0,26$ & 2,56 \\
\hline 19 & $-0,076$ & $-0,076$ & $-2,8$ & 0,37 & 2,542 & 0,07 & 2,283 & 0,37 & 2,283 & $-0,43$ & $-5,209$ & $-0,62$ & $-6,62$ & & 0,15 & $-0,23$ & 0,828 \\
\hline 20 & 0,224 & 0,224 & $-3,3$ & 0,3 & 2,149 & 0,1 & 2,313 & 0,4 & 2,313 & 0,6 & $-4,102$ & 0,4 & $-6,6$ & & 0,2 & $-0,2$ & 1,028 \\
\hline 21 & 0,524 & 0,524 & $-2,8$ & 0,13 & 1,978 & 0,13 & 2,343 & 0,43 & 2,343 & 0,63 & $-3,401$ & 0,42 & $-7,58$ & & $-6,75$ & 0,83 & 0,084 \\
\hline 22 & 0,797 & 0,797 & $-2,3$ & 0,06 & 2,725 & 0,16 & 2,273 & 0,46 & 2,273 & 0,66 & $-2,22$ & 0,04 & $-7,56$ & & $-6,7$ & 0,86 & 2,411 \\
\hline 23 & 0,404 & 0,404 & $-2,6$ & 0,09 & 2,31 & 0,19 & 2,103 & 0,49 & 2,103 & 0,69 & $-1,854$ & 0,06 & $-7,54$ & & $-6,65$ & 0,89 & 0,630 \\
\hline 24 & 0 & 0 & $-2,1$ & 0,12 & 1,608 & $-0,084$ & 2,133 & 0,216 & 2,133 & $-0,584$ & 0,673 & 0,08 & $-8,52$ & & $-7,5$ & 0,92 & 0,152 \\
\hline 25 & & & $-1,6$ & 0,15 & 0,966 & $-0,054$ & 0,763 & 0,246 & 0,763 & $-1,554$ & 2,121 & $-2,5$ & $-9,5$ & & $-7,35$ & 0,53 & 0 \\
\hline \multirow[t]{5}{*}{26} & & & $-1,1$ & 0,08 & 1,11 & $-0,424$ & 0,196 & $-0,12$ & 0,196 & $-1,924$ & 3,53 & $-4,48$ & $-8,896$ & & $-6,3$ & 0,28 & \\
\hline & & & $-0,6$ & 0 & 0,541 & $-0,394$ & 0 & $-0,09$ & 0 & $-1,894$ & 4,506 & $-4,46$ & $-8,876$ & & $-6,25$ & 0,31 & \\
\hline & & & $-0,1$ & & 1,481 & 0 & & 0 & & 0 & 5,499 & $-5,44$ & $-8,856$ & & $-6,1$ & 0,34 & \\
\hline & & & 0,4 & & 1,731 & & & & & & 5,615 & $-6,42$ & $-8,836$ & & $-6,05$ & 0 & \\
\hline & & & 0,9 & & 1,865 & & & & & & 3,91 & $-7,4$ & 0 & & $-6,2$ & & \\
\hline
\end{tabular}




\begin{tabular}{|c|c|c|c|c|c|c|c|c|c|c|c|c|c|c|c|c|c|}
\hline & & & 1,4 & & 2,182 & & & & & & 2,974 & $-8,38$ & & & $-6,25$ & & \\
\hline & & & 1,9 & & 2,427 & & & & & & 2,599 & $-9,36$ & & & $-7,2$ & & \\
\hline & & & $-0,6$ & & 1,272 & & & & & & 2,721 & $-9,44$ & & & -7 & & \\
\hline & & & 2,9 & & 1,844 & & & & & & 2,208 & $-9,42$ & & & 0 & & \\
\hline & & & 3,4 & & 1,549 & & & & & & 1,553 & $-9,4$ & & & & & \\
\hline & & & 3,9 & & 0,249 & & & & & & 1,275 & $-8,68$ & & & & & \\
\hline & & & 4,4 & & 0,09 & & & & & & 0,801 & $-8,56$ & & & & & \\
\hline & & & 4,9 & & $-0,408$ & & & & & & 0,557 & $-8,64$ & & & & & \\
\hline & & & 4,6 & & $-1,138$ & & & & & & 0 & $-8,62$ & & & & & \\
\hline & & & 4,107 & & $-0,83$ & & & & & & & $-8,64$ & & & & & \\
\hline & & & 3,727 & & $-0,111$ & & & & & & & $-8,76$ & & & & & \\
\hline & & & 3,346 & & $-0,001$ & & & & & & & $-8,74$ & & & & & \\
\hline & & & 2,966 & & 0 & & & & & & & $-8,72$ & & & & & \\
\hline & & & 2,585 & & & & & & & & & 0 & & & & & \\
\hline & & & 2,348 & & & & & & & & & & & & & & \\
\hline & & & 2,568 & & & & & & & & & & & & & & \\
\hline & & & 2,788 & & & & & & & & & & & & & & \\
\hline & & & 3,008 & & & & & & & & & & & & & & \\
\hline & & & 3,228 & & & & & & & & & & & & & & \\
\hline & & & 3,448 & & & & & & & & & & & & & & \\
\hline & & & 3,668 & & & & & & & & & & & & & & \\
\hline & & & 2,815 & & & & & & & & & & & & & & \\
\hline & & & 1,807 & & & & & & & & & & & & & & \\
\hline & & & 0,7 & & & & & & & & & & & & & & \\
\hline & & & 0 & & & & & & & & & & & & & & \\
\hline Durasi (D) & 24 & 24 & 55 & 27 & 43 & 28 & 27 & 28 & 27 & 26 & 39 & 44 & 30 & 18 & 34 & 29 & 21 \\
\hline $25 \% * \mathrm{D}$ & 6 & 6 & 14 & 7 & 11 & 7 & 7 & 7 & 7 & 7 & 10 & 11 & 8 & 5 & 9 & 7 & 5 \\
\hline $30 \% * \mathrm{D}$ & 7 & 7 & 17 & 8 & 13 & 8 & 8 & 8 & 8 & 8 & 12 & 13 & 9 & 6 & 10 & 9 & 6 \\
\hline $50 \% \mathrm{D}$ & 12 & 12 & 28 & 14 & 22 & 14 & 14 & 14 & 14 & 13 & 20 & 22 & 15 & 9 & 17 & 15 & 11 \\
\hline $\operatorname{Sim}(25 \% * \mathrm{D})$ & 1,173 & 1,173 & $-0,3$ & 0,21 & $-2,45$ & $-0,09$ & 1,002 & $-0,09$ & 1,002 & $-0,89$ & $-12,229$ & 0,02 & $-2,84$ & 1 & 0,45 & 0,21 & $-2,9$ \\
\hline $\operatorname{Sim}(30 \% * \mathrm{D})$ & 1,029 & 1,029 & $-1,8$ & 0,24 & $-2,088$ & 0,54 & 6,104 & $-0,46$ & 6,104 & $-0,96$ & $-11,773$ & $-0,64$ & 0,18 & 1,2 & $-0,3$ & $-0,53$ & $-1,087$ \\
\hline $\operatorname{Sim}(50 \% * \mathrm{D})$ & $-3,418$ & $-3,418$ & $-0,1$ & 0,42 & 2,725 & $-0,08$ & 2,133 & $-0,38$ & 2,133 & $-1,01$ & $-4,102$ & 0,04 & 0,3 & 0 & 0,05 & 0,65 & 2,447 \\
\hline
\end{tabular}


Table 2. Expected Value Progress 17 Construction Works

\begin{tabular}{lcccc}
\hline Progres & Pesimistik & mostlikely & optimistik & Ecpected \\
\hline $\operatorname{Sim}(25 \% * \mathrm{D})$ & $-12,23$ & $-0,915$ & 1,173 & $-2,452$ \\
\hline $\operatorname{Sim}(30 \% * \mathrm{D})$ & $-11,77$ & $-0,189$ & 6,104 & $-1,071$ \\
\hline $\operatorname{Sim}(50 \% * \mathrm{D})$ & $-4,102$ & $-0,095$ & 2,725 & $-0,293$
\end{tabular}

Source: processed data

\section{Conclusion and Suggestion}

\subsection{Conclusion}

- The deviation value varies according to the completed construction work. The increase in the value of the variation in the positive direction occurs concurrently with a $25 \%$ increase in the percentage of duration starting time (-2.425), a 30\% increase in the percentage of duration starting time (1.071), and a 50\% increase in the percentage of duration starting time (-2.425). (2.275).

- The increase in the positive deviation value is due to the fact that much work can be done concurrently by optimizing human resources and equipment.

\subsection{Suggestion}

This research still has numerous shortcomings and should be redeveloped. The increase in the number of construction projects of nearly identical type and size requires investigation. As a result, the problem-solving approach is more focused. .

\section{References}

[1] S. Robintang Tua and Mardiaman, "Pengendalian Biaya Menggunakan Metode Hasil Pelaksanaan Proyek (kasus: Pembangunan Pabrik Kelapa Sawit)," in Konferensi Nasional Teknik Sipil 10, 2016, pp. 31-40.

[2] R. U. Farooqui, E. Hussain, M. Umer, and S. H. Lodi, "Factors Affecting Construction Cost in the Pakistani Construction Industry," in Third International Conference on Construction in Developing Countries (ICCIDC-III), 2012, no. July, pp. 161-168.

[3] O. Bamitale, Aiyewalehinmi, and O. . Omolayo, "Most Critical Factors Responsible For Cost Overruns In Nigeria Building Construction Industry," J. Multidiscip. Eng. 
Sci. Stud., vol. 5, no. February, pp. 2500-2507, 2019, doi:

10.13140/RG.2.2.35471.74401.

[4] M. Sulaiman, “Analisis Penyebab Keterlambatan Pelaksanaan Proyek Ditinjau Dari Waktu Pelaksanaan Di Provinsi Aceh,” J. Tek. Sipil, vol. 1, no. 2, pp. 405-418, 2017.

[5] Mardiaman and Indriasari, "FAKTOR-FAKTOR PENENTU UTAMA KETERLAMBATAN PADA PEKERJAAN KONSTRUKSI PABRIK ( STUDI KASUS : PABRIK KAWASAN CIKARANG ) Pekerjaan konstruksi sifatnya sangat tidak pasti . Waktu selesainya setiap item pekerjaan dalam lingkup proyek bisa cepat dan lambat . Ket," e-Journal CENTECH 2020, vol. 2, no. 1, pp. 1-11, 2021.

[6] Junaidi, H. Tarore, G. Y. Malingkas, and D. R. O. Walangitan, "Pengendalian Waktu Dan Biaya Pada Tahap Pelaksanaan Proyek Dengan Menggunakan Metode Nilai Hasil (Studi Kasus : Proyek Lanjutan Pembangunan Gedung PIP2B Kota Manado),” J. Sipil Statik, vol. 1, no. 1, pp. 44-52, 2012.

[7] D. K. Sudarsana, "PENGENDALIAN BIAYA DAN JADUAL TERPADU PADA PROYEK KONSTRUKSI.,” J. Ilm. Tek. Sipil, vol. 12, no. 2, pp. 187-195, 2008.

[8] J. Zawistowski, "Application of modified earned value method for assessing the risk and progress of construction projects," Mod. Build. Mater. Struct. Tech., no. Pmi, pp. $557-560,2010$.

[9] T. Baumann, A. Dziadosz, Ol. Kaplinski, and M. Rejment, "Range of Aplication and Limitations of the Earned Value Method in Construction Project Estimation Zakres Stosowania I Ograniczenia Metody Earned Value Do Oceny Przedsięwzięcia,” Tech. Trans. Civ. Eng., 2014.

[10] M. Fauzan and Mawardi, "Evaluasi Kemajuan Proyek Dengan Metode Pengendalia Kinerja Nilai Hasil Proses Waktu Dan Biaya," J. Penelit. Tek. Inform. Univ. Malikussaleh, Lhokseumawe Aceh, vol. 2, no. 1, pp. 77-88, 2015.

[11] A. Czarnigowska, "Earned value method as a tool for project control," Bud. i Archit., vol. 3, no. 2, pp. 015-032, 2008, doi: 10.35784/bud-arch.2320.

[12] M. S. Sauain, T. A. T. Mahmood, and T. Mahmood, "Monitoring project performance through earned value analysis," in Proceedings of the 2013 International Conference on Information, Operations Management and Statistics (ICIOMS2013), 2013, pp. 2-6. 
[13] Noumeiry and A. Mursadin, "Kajian Faktor-Faktor Yang Berpengaruh Terhadap Kinerja Proyek Gedung di Kota Samarinda,” J. Teknol. Berkelanjutan, vol. 2, no. 1, pp. 29-40, 2017.

[14] M. Nadiasa, A. A. D. P. Dewi, and S. Pameke, "Analisis Pengaruh Lokasi Terhadap Biaya Proyek Irigasi (Studi Kasus : Pengangkutan Material Ke Lokasi Proyek Irigasi Di Kabupaten Gianyar),” J. Ilm. Tek. Sipil, vol. 18, no. 2, pp. 130-136, 2014.

[15] Mardiaman, "Proportion Of Resource Component Cost In Multi-Story Buildings : Indonesia Case," Solid State Technol., vol. 63, no. 5, pp. 5785-5794, 2020.

[16] J. Atmaja, E. R. Syofyan, and A. Fadillah, "Perbandingan Cost Significant Model Dengan Metode Parametrik Untuk Estimasi Biaya Gedung Bertingkat 2 di Provinsi Sumatera Barat Comparison of Cost Significant Models with Parametric Methods for Estimating the Cost of 2-Storey Buildings in Sumatra Provinc," vol. 14, pp. 43-57, 2018.

[17] A. Asmi and J. C. S. Pratama, "Identifikasi Faktor-Faktor Keterlambatan Dalam Proyek Konstruksi Di Jakarta,” in jurnal.umj.ac.id/index.php/semnastek, 2016, no. November, pp. 1-12.

[18] H. Hassan, J. B. Mangare, and P. A. K. Pratasis, "Faktor-faktor penyebab keterlambatan pada proyek konstruksi dan alternatif penyelesaiannya (studi kasus : di manado town square III)," J. Sipil Statik Vol.4, vol. 4, no. 11, pp. 657-664, 2016.

[19] L. Le-Hoai, Y. D. Lee, and J. Y. Lee, "Delay and cost overruns in Vietnam large construction projects: A comparison with other selected countries," KSCE J. Civ. Eng., vol. 12, no. 6, pp. 367-377, 2008, doi: 10.1007/s12205-008-0367-7.

[20] M. Głuszak and A. Les̈niak, "Construction Delays in Clients Opinion - Multivariate Statistical Analysis," Procedia Eng., vol. 123, pp. 182-189, 2015, doi: 10.1016/j.proeng.2015.10.075.

[21] R. F. Aziz and A. A. Abdel-Hakam, "Exploring delay causes of road construction projects in Egypt," Alexandria Eng. J., vol. 55, no. 2, pp. 1515-1539, 2016, doi: 10.1016/j.aej.2016.03.006.

[22] T. Gebrehiwet and H. Luo, "Analysis of Delay Impact on Construction Project Based on RII and Correlation Coefficient: Empirical Study," 2017, doi: 10.1016/j.proeng.2017.07.212. 
[23] M. M. Marzouk and T. I. El-Rasas, "Analyzing delay causes in egyptian construction projects," J. Adv. Res., vol. 5, no. 1, pp. 49-55, 2014, doi: 10.1016/j.jare.2012.11.005.

[24] D. Astina, I. Widhiawati, and I. Joni, “Analisis Faktor-Faktor Penyebab Keterlambatan Pelaksanaan Pekerjaan Proyek Konstruksi Di Kabupaten Tabanan," J. Ilm. Elektron. Infrastruktur Tek. Sipil, vol. 1999, 2012.

[25] S. K. Bhosekar and G. Vyas, "Cost Controlling Using Earned Value Analysis in Construction Industries," Int. J. Eng. Innov. Technol., vol. 1, no. 4, pp. 324-332, 2012, [Online]. Available:

https://www.researchgate.net/profile/Gayatri_Vyas2/publication/265285339_Cost_Co ntrolling_Using_Earned_Value_Analysis_in_Construction_Industries/links/553b16c5 0cf2c415bb08ffcf/Cost-Controlling-Using-Earned-Value-Analysis-in-ConstructionIndustries.pdf.

[26] J. Konior and M. Szóstak, "The S-curve as a tool for planning and controlling of construction process-case study," Appl. Sci., vol. 10, no. 6, 2020, doi: 10.3390/app10062071.

[27] D. Przywara and A. Rak, "Monitoring of time and cost variances of schedule using simple earned value method indicators," Appl. Sci., vol. 11, no. 4, pp. 1-13, 2021, doi: 10.3390/app11041357.

[28] Bharath Arunmozhi K M and P. K. C, "Study On Project Forecasting and Control In Residential Building Using Earned Value Management," vol. 7, no. 2, pp. 301-308, 2018.

[29] M. Gerawork Jembere, B. Bewket Mitikie, and E. Kelemework Yigzaw, "Performance Evaluation of Housing Construction Project, Using Earned Value Analysis; the Case of 20/80 Condominium Addis Ababa Bole Arabsa Site," Am. J. Eng. Technol. Manag., vol. 5, no. 4, p. 69, 2020, doi: 10.11648/j.ajetm.20200504.12.

[30] A. Czemplik, "Application of earned value method to progress control of construction projects," Procedia Eng., vol. 91, no. TFoCE, pp. 424-428, 2014, doi: 10.1016/j.proeng.2014.12.087.

[31] T. Baumann, Agnieszka, O. Kaplinski, and M. Rejment, "Range of aplication and limitations of the earned value method in construction project estimation," Czas. 
Tech., vol. 2, pp. 65-72, 2014, doi: 10.4467/2353737XCT.14.113.2563.

[32] M. I. Pedro, J. Pereira, J. A. Filipe, and M. A. M. Ferreira, "An Approach to Earned Value Analysis (EVA): An Application to a Practical Case," Int. J Latest Trends Fin. Eco. Sc., vol. 1, no. 2, pp. 63-73, 2011, [Online]. Available: http://repositorioiul.iscte.pt/handle/10071/5615.

[33] M. T. Sitompul, "Penerapan Metode Monte Carlo Penjadwalan Proyek Konstruksi ( Studi Kasus : Proyek Pembangunan Apartemen The Reiz Condo Medan ),” North Sumatera University, 2018.

[34] S. Milah, D. Nurmayadi, and A. R. Hendardi, "Analisis Pengendalian Waktu Proyek Konstruksi Menggunakan Earned Value Concept (EVC) Dan Critical Path Method (CPM)," J. Ilm. Tek. Sipil, vol. 1, no. 1, pp. 1-14, 2019.

[35] M. Priyo and N. A. Wibowo, "Konsep Earned Value dalam Aplikasi Pengelolaan Proyek Konstruksi,” J. Ilm. Semesta Tek., vol. 11, no. 2, pp. 153-161, 2008.

[36] Y. Frimpong, J. Oluwoye, and L. Crawford, "Causes of delay and cost overruns in construction of groundwater projects in a developing countries; Ghana as a case study," Int. J. Proj. Manag., vol. 21, no. 5, pp. 321-326, 2003, doi: 10.1016/S02637863(02)00055-8.

[37] Mardiaman, "DETERMINING WEIGHTCRITERIA / SUB-CRITERIA IN SELECTING," Palarch's J. Archaeol. Egypt/Egyptology, vol. 17, no. 9, pp. 94859495, 2020, [Online]. Available:

https://archives.palarch.nl/index.php/jae/article/view/5910/5786. 